\title{
Haemogregarines of the genus Hepatozoon (Apicomplexa: Adeleina) in rodents from northern Europe
}

\author{
Juha Laakkonen ${ }^{1}$, Antti Sukura ${ }^{2}$, Antti Oksanen $^{3}$, Heikki Henttonen $^{4}$ and Timo Soveri ${ }^{2}$ \\ ${ }^{1}$ Department of Biology, University of California, San Diego, 9500 Gilman Drive, La Jolla, California 92093-0116, USA; \\ ${ }^{2}$ Department of Basic Veterinary Sciences, Faculty of Veterinary Medicine, University of Helsinki, P.O. Box 57, FIN-00014 \\ Helsinki, Finland; \\ ${ }^{3}$ The Norwegian School of Veterinary Science, Department of Arctic Veterinary Medicine, N-9292 Tromsø, Norway; \\ ${ }^{4}$ Finnish Forest Research Institute, P.O. Box 18, FIN-01301 Vantaa, Finland
}

Key words: Hepatozoon, morphology, rodents, meront

\begin{abstract}
We studied the prevalence and distribution of Hepatozoon infections in small rodents from Finland and other areas in northern Europe. Hepatozoon infections were more common in voles (Arvicolinae) than mice (Murinae) and more prevalent in voles of the genus Clethrionomys than in voles of the genus Microtus. Transmission electron microscopical examination of Hepatozoon erhardovae Krampitz, 1964 from bank voles Clethrionomys glareolus (Schreber) showed that intracellular lung meronts were located in alveolar septa. Meronts consisted of varying numbers of merozoites packed with amylopectin vacuoles inside electron-lucent parasitophorous vacuole. The size of the meronts was approximately $19 \times 14 \mu \mathrm{m}$. Monozoic or dizoic cysts were frequent findings in the lung alveoles; the size of cysts was approximately $10 \times 6 \mu \mathrm{m}$. Gametocytes were found inside eosinophilic granulocytes in the capillaries of lung tissue. Ultrastructurally, micronemes, microtubules, mitochondria, nuclei and lipid droplets were visible.
\end{abstract}

The genus Hepatozoon Miller, 1908 consists of apicomplexan blood parasites that have been described from a wide range of mammals and other vertebrates, especially reptilians and amphibians (Levine 1982, Smith 1996). Sexual stage with sporogony takes place in different blood-sucking arthropods, and asexual phase in endothelial cells of various organs or parenchymal cells of the liver, according to the species of parasite and the intermediate vertebrate host. Intracellular gametocytes are found in circulation either in erythrocytes or in leukocytes. Surveys of small mammals in Central Europe (Mahnert 1972, Frank 1977, Šebek 1978, Šebek et al. 1980, Walter and Liebisch 1980, Healing 1981, Turner 1986) indicate that Hepatozoon infections are especially common in the bank vole, Clethrionomys glareolus (Schreber). One species, Hepatozoon erhardovae Krampitz, 1964, has the bank vole as the type host.

There are only a few reports of Hepatozoon infections in small mammals from northern Europe (Tadros, cited in Killick-Kendrick 1974, Wiger 1979, Soveri et al. 2000). In this paper we report prevalence and distribution data of Hepatozoon infections of small rodents from Finland and some other areas in northern Europe. Furthermore, we examine the morphology of different life-cycle forms of $H$. erhardovae found in bank voles from central Finland.

\section{MATERIALS AND METHODS}

The rodents analysed in this survey were captured using live traps (Ugglan special, Allan Ahlgren AB, Marieholm, Sweden) as part of studies investigating diseases of small mammals (Laakkonen et al. 1999, Nemirov et al. 1999, Soveri et al. 2000). The study areas, rodent species and number of individuals examined are shown in Table 1. Kilpisjärvi is in the subarctic birch forest zone, and Pallasjärvi in the northern taiga forest zone in Finnish Lapland. Heinola, Evo and Luhanka are in the boreal zone in southern and central Finland. In Russian Karelia, rodents were collected from several areas in the boreal forests in the eastern part of the republic. In Estonia, rodents were trapped in mixed deciduous forests and oak forests of the Saaremaa Island. The Evo material covers two peak density (in the autumn) phases, and the following crash phases (the next spring) of cyclic Microtus agrestis (Linnaeus) populations. The Luhanka material covers similar peak/crash phase (1991-1992), an autumn of an increasing population density (1993), and an autumn of a peak density (1994).

Animals were euthanised with ether and tissue samples from the lungs (right cranial and medial lobes), liver (near the edge of the largest lobe), stomach (fundus), intestines (midjejunum and on the top of the colonal spiral), and transversal sections from the middle of the heart, spleen, right kidney, and brain were fixed in $10 \%$ buffered formalin, and embedded in paraffin to make standard histological sections, which were stained with haematoxylin and eosin (H\&E). Samples were screened for meronts (=schizonts) and other life-cycle forms 
with a light microscope at $\times 200$ and $\times 400$ magnification. Sections of some paraffin-embedded Hepatozoon-positive lung tissue were also stained with PAS (periodic acid-Schiff) and GMS (Gomori's methenamine silver) stainings. For electron microscopical examination, lung samples were fixed with $2.5 \%$ glutaraldehyde buffered with $0.1 \mathrm{M}$ phosphate buffer, $\mathrm{pH} 7.2$, for $1 \mathrm{~h}$ at $20^{\circ} \mathrm{C}$. After being rinsed with several aliquots of phosphate buffer, the samples were post-fixed in phosphate buffered $1 \%$ osmium tetroxide for $1 \mathrm{~h}$ at $4{ }^{\circ} \mathrm{C}$ and embedded in Epon after dehydration in ethanol. Ultrathin sections were stained with 3\% uranyl acetate and 3\% lead citrate. TEM observations were made with a JEOL $100 \mathrm{~S}$ electron microscope (JEOL Ltd., Tokyo, Japan).

Statistix for Windows 2.0 statistical software package was used in all analyses (Analytical Software, Tallahassee, FL, USA).

\section{RESULTS}

Forms of Hepatozoon haemogregarines were only found in the lungs of the host animals, meronts specifically in the alveolar septa and also close to it free in the alveolus space. Empty looking halo (parasitophorous vacuole) surrounded the meronts. Observed tissue reactions in infected lungs were minimal (Fig. 1). The meronts showed reactivity with both PAS and GMS staining.

In bank voles, the parasite was identified as $H$. erhardovae, based on morphology (Frank 1977, Krampitz 1981) and the previous reports associating this parasite with the bank vole (Šebek et al. 1980, Walter and Liebisch 1980, Turner and Cox 1985). In transmission electron microscopy intracellular meronts were found located in alveolar septa. Inside electronlucent parasitophorous vacuole, varying numbers of merozoites were packed together with amylopectin granules in meronts. The size of the parasitophorous vacuoles was approximately $22 \times 18 \mu \mathrm{m}$, and that of the meronts $19 \times 14 \mu \mathrm{m}$. The different consistency of meronts compared to lung tissue was demonstrated by their tendency to rip off during preparation of ultrathin sections (Fig. 2). Gametocytes were found inside eosinophilic granulocytes in the capillaries of lung tissue. Ultrastructurally, micronemes, microtubules, mitochondria, nuclei and lipid droplets were seen (Fig. 3 ). The granulocytes appeared to have suffered from being parasite-laden, karyopyknosis was often evident. Intra-alveolar monozoic or dizoic cysts, approximately $10 \times 6 \mu \mathrm{m}$ in size, were also commonly seen (Fig. 4).

The prevalence of Hepatozoon meronts in different host species is shown in Table 1. Forms of Hepatozoon were prevalent in all three Clethrionomys species occurring in the study areas but infection was found only occasionally in Microtus species. Hepatozooninfected mice were not found. In $C$. glareolus, no association between sex and age of the animal and occurrence of Hepatozoon was found. In that species, infections were observed in all seasons.

\section{DISCUSSION}

In the present study, the predilection site of Hepatozoon meronts was the lungs, and that of gametocytes was leukocytes, intriguingly especially eosinophilic granulocytes. We did not investigate blood smears; that would have revealed if gametocyte-laden eosinophilic granulocytes were in the general circulation. The tissue tropism varies greatly between animal species, also within mammals (Yanai et al. 1995, Smith 1996, Panciera et al. 2000). Only minimal tissue reactions were detected, and no clinically ill rodents were observed, but in experimental infections, mortality due to $H$. erhardovae has been reported (Krampitz and Haberkorn 1988). Monozoic or dizoic tissue cysts rather similar but sturdier $(10 \times 6 \mu \mathrm{m}$ compared to $9 \times 2 \mu \mathrm{m})$ than those observed in squirrels (Desser 1990) were commonly seen in lung alveoles of $C$. glareolus. In squirrels, all cysts were monozoic, but in reptile species dizoic cysts have been reported (Landau et al. 1972).

Compared to host cells, developing meronts are large (Fig. 2). It is of interest that gametocytes appeared to be ultrastructurally intact (Fig. 3) inside the eosinophilic granulocytes, which are thought to act in the antiparasitic defence. On the other hand, the eosinophiles appeared to have suffered. Pyknotic nuclei of granulocytes were also observed in Japanese martens in phagocytes containing merozoites (Yanai et al. 1995).

Results of this study indicate that Hepatozoon haemogregarines are more common in voles (Arvicolinae) than mice (Murinae). Furthermore, Hepatozoon infection is more prevalent in voles of the genus Clethrionomys than in voles of the genus Microtus. Šebek (1975) reported similar results from small mammals in Czechoslovakia. The difference between Clethrionomys and Microtus species does not appear to be associated with definitive flea hosts; our own observations (H. Henttonen, unpublished) support those by Savitskii and Kulnazarov (1988), who found no Microtus oeconomus-specific fleas or other ectoparasites, but fleas were shared with other vole species, including bank voles.

Seasonal (Wiger 1979, Turner 1986) and annual (Healing 1981) differences in the occurrence of blood forms of Hepatozoon have previously been reported from rodents in northern and Central Europe. In the present study, lung meronts were common in $C$. glareolus in all seasons (Table 1). A possible explanation to this difference is that the blood forms are associated to the transmission to definitive arthropod hosts, and therefore only are present when bloodsucking arthropods are active, but meronts represent a more slowly reacting stage of the parasite. In $M$. agrestis, most infected individuals were found during the autumn. However, the prevalence was low even when highest. 

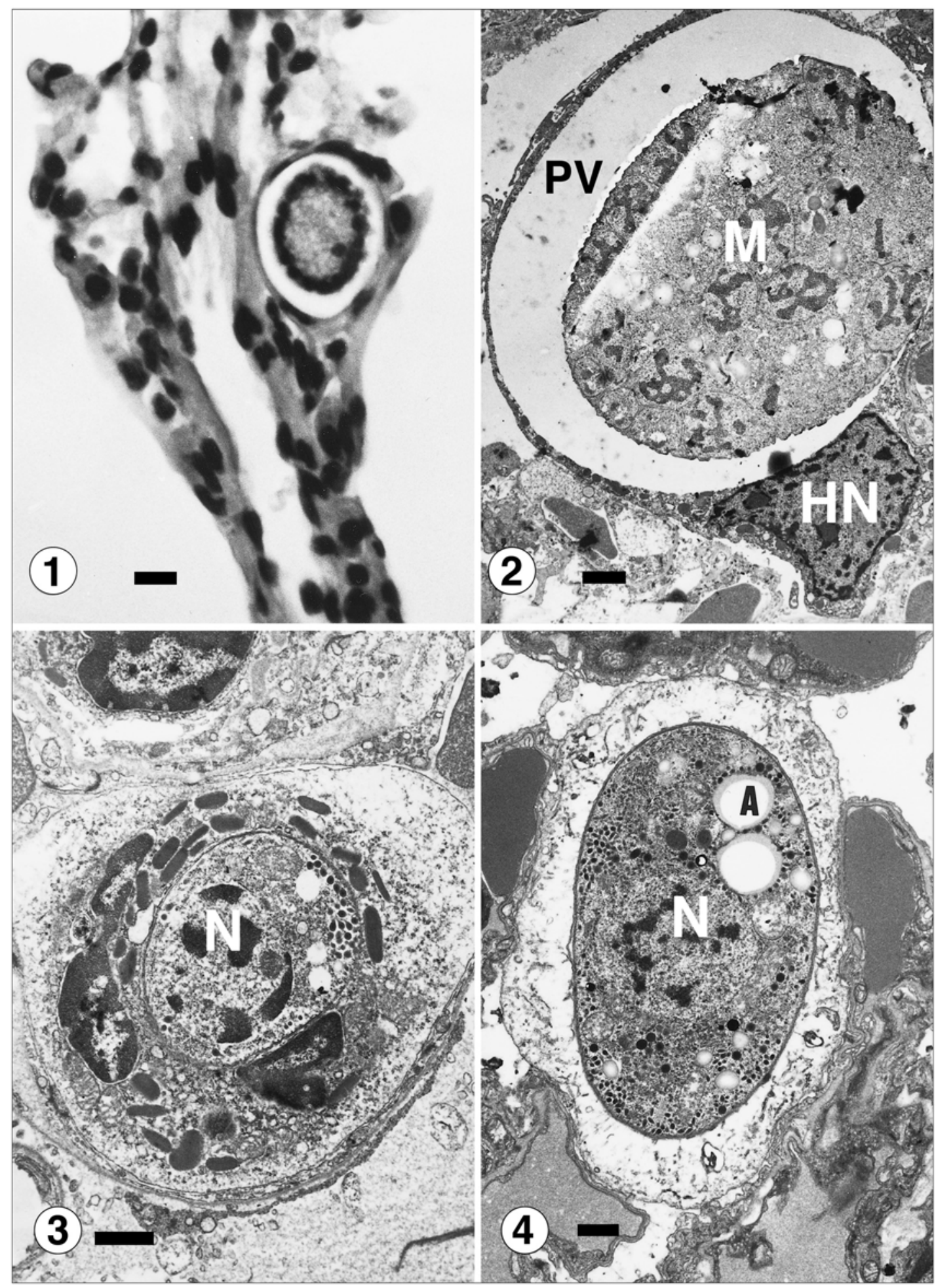

Fig. 1. Hepatozoon erhardovae-infected lung of Clethrionomys glareolus. Meront in alveolar septum. Parasitophorous vacuole surrounds the meront inside the host cell. Histological section, H\&E. Figs. 2-4. Life-cycle stages of Hepatozoon erhardovae in pulmonary tissue of Clethrionomys glareolus. Transmission electron micrographs. Fig. 2. Meront. Numerous merozoites (M) and amylopectin vacuoles (A) are inside electron-lucent parasitophorous vacuole (PV); the nucleus of host cell (HN) is compressed to periphery of the cell. Fig. 3. Gametocyte inside the circulating eosinophilic granulocyte. Note typical eosinophilic granules with electron-dense crystals. Nucleus of the parasite (N). Fig. 4. Monozoic cyst form. Nucleus (N), amylopectin (A). Scale bars: Fig. 1 $=5 \mu \mathrm{m}$; Fig. $2=2 \mu \mathrm{m}$; Figs. 3, $4=1 \mu \mathrm{m}$. 
Table 1. Lung meronts of Hepatozoon sp./spp. in voles of the genus Clethrionomys and Microtus and in mice of the genus Apodemus from Finland and some other locations in northern Europe. + - number of infected; $\mathrm{n}$ - number of examined; \% prevalence.

\begin{tabular}{|c|c|c|c|c|c|c|}
\hline Host species & Locality & Coordinates & Month & Year & $+/ \mathrm{n}$ & $\%$ \\
\hline Clethrionomys rufocanus (Sundevall) & Kilpisjärvi & $69^{\circ} 03^{\prime} \mathrm{N}, 20^{\circ} 49^{\prime} \mathrm{E}$ & September & 1989 & $7 / 30$ & 23 \\
\hline Clethrionomys rutilus (Pallas) & Eastern Karelia, Russia & $62^{\circ} \mathrm{N}, 34^{\circ} \mathrm{E}$ & August & 1996 & $2 / 3$ & 67 \\
\hline \multirow{8}{*}{ Clethrionomys glareolus (Schreber) } & \multirow[t]{4}{*}{ Pallasjärvi } & \multirow[t]{4}{*}{$68^{\circ} 03^{\prime} \mathrm{N}, 24^{\circ} 09^{\prime} \mathrm{E}$} & June & 1988 & $20 / 45$ & 44 \\
\hline & & & September & 1988 & $14 / 41$ & 34 \\
\hline & & & November & 1988 & $23 / 47$ & 49 \\
\hline & & & February & 1989 & $24 / 44$ & 55 \\
\hline & \multirow{4}{*}{$\begin{array}{l}\text { Heinola } \\
\text { Eastern Karelia, Russia } \\
\text { Saaremaa, Estonia }\end{array}$} & \multirow{4}{*}{$\begin{array}{l}61^{\circ} 14^{\prime} \mathrm{N}, 26^{\circ} 02^{\prime} \mathrm{E} \\
58^{\circ} 16^{\prime} \mathrm{N}, 22^{\circ} 29^{\prime} \mathrm{E}\end{array}$} & June-Dec & 1988 & $2 / 22$ & 18 \\
\hline & & & August & 1996 & $18 / 43$ & 42 \\
\hline & & & November & 1997 & $16 / 28$ & 57 \\
\hline & & & & Total & $117 / 270$ & 43 \\
\hline \multirow[t]{18}{*}{ Microtus agrestis (Linnaeus) } & \multirow{8}{*}{$\begin{array}{l}\text { Heinola } \\
\text { Evo }\end{array}$} & \multirow{8}{*}{$61^{\circ} 10^{\prime} \mathrm{N}, 25^{\circ} 03^{\prime} \mathrm{E}$} & June & 1988 & $1 / 39$ & 3 \\
\hline & & & September & 1989 & $0 / 13$ & - \\
\hline & & & November & 1989 & $1 / 46$ & 2 \\
\hline & & & February & 1990 & $0 / 18$ & - \\
\hline & & & March & 1990 & $0 / 24$ & - \\
\hline & & & September & 1992 & $1 / 51$ & 2 \\
\hline & & & November & 1992 & $2 / 50$ & 4 \\
\hline & & & January & 1993 & $2 / 49$ & 4 \\
\hline & \multirow[t]{7}{*}{ Luhanka } & \multirow{10}{*}{$61^{\circ} 48^{\prime} \mathrm{N}, 25^{\circ} 45^{\prime} \mathrm{E}$} & September & 1991 & $3 / 45$ & 7 \\
\hline & & & November & 1991 & $0 / 50$ & - \\
\hline & & & January & 1992 & $0 / 49$ & - \\
\hline & & & March & 1992 & $0 / 44$ & - \\
\hline & & & September & 1993 & $0 / 24$ & - \\
\hline & & & November & 1993 & $1 / 36$ & 3 \\
\hline & & & November & 1994 & $0 / 96$ & - \\
\hline & & & August & 1996 & $1 / 6$ & 17 \\
\hline & \multirow{2}{*}{ Saaremaa, Estonia } & & November & 1997 & $0 / 7$ & - \\
\hline & & & & Total & 11 / 647 & 2 \\
\hline Microtus arvalis (Pallas) & Saaremaa, Estonia & & October & 1996 & $0 / 69$ & - \\
\hline \multirow[t]{2}{*}{ Apodemus agrarius (Pallas) } & \multirow[t]{2}{*}{ Saaremaa, Estonia } & & October & 1996 & $0 / 111$ & - \\
\hline & & & November & 1997 & $0 / 63$ & - \\
\hline \multirow[t]{2}{*}{ Apodemus flavicollis (Melchior) } & \multirow[t]{2}{*}{ Saaremaa, Estonia } & & October & 1996 & $0 / 7$ & - \\
\hline & & & November & 1997 & $0 / 45$ & - \\
\hline
\end{tabular}

Only one haemogregarine species, Hepatozoon erhardovae, has commonly been described from $C$. glareolus. Other species names have been occasionally used (see Šebek 1975) but while C. glareolus is the specific host for $H$. erhardovae other, non-specific host mammals may be infected with it sometimes (Frank 1977). Molecular studies on the intermediate host- species specificity of Hepatozoon spp. in rodents are warranted.

Acknowledgements. The Academy of Finland has financially supported our disease studies of small mammals. We are also very grateful to two anonymous reviewers for many constructive remarks.

\section{REFERENCES}

DESSER S.S. 1990: Tissue "cysts" of Hepatozoon griseisciuri in the grey squirrel, Sciurus carolinensis: the significance of these cysts in the species of Hepatozoon. J. Parasitol. 76: $257-259$.

FRANK C. 1977: Ein Beitrag zur Biologie von Hepatozoon erhardovae Krampitz 1964 in Rötelmäusen aus der Südweststeiermark und des Neusiedlerseegebietes (Burgenland). Z. Parasitenkd. 53: 251-254.

HEALING T.D. 1981: Infections with blood parasites in the small British rodents Apodemus sylvaticus, Clethrionomys glareolus and Microtus agrestis. Parasitology 83: 179-189.
KILLICK-KENDRICK R. 1974: Parasitic protozoa of the blood of rodents. Acta Trop. 31: 29-69.

KRAMPITZ H.E. 1981: Development of Hepatozoon erhardovae Krampitz, 1964 (Protozoa: Haemogregarinidae) in experimental mammalian and arthropod hosts. II. Sexual development in fleas and sporozoite indices in xenodiagnosis. Trans. R. Soc. Trop. Med. Hyg. 75: 155157.

KRAMPITZ H.E., BÄUMLER W. 1978: Vorkommen, Saisondynamik und Wirtskreis von Babesia microti (Franca, 1912) in einheimischen Nagetieren. Z. Parasitenkd. 58: 15-33. 
KRAMPITZ H.E., HABERKORN A. 1988: Experimental treatment of Hepatozoon infections with the anticoccidial agent toltrazuril. J. Vet. Med. Series B 35: 131-137.

LAAKKONEN J., HENTTONEN H., NIEMIMAA J., SOVERI T. 1999: Seasonal dynamics of Pneumocystis carinii in the field vole, Microtus agrestis, and in the common shrew, Sorex araneus, in Finland. Parasitology 118: $1-5$.

LANDAU I., MICHEL J.C., CHABAUD A.G., BRYGOO E.R. 1972: Cycle biologique d'Hepatozoon domerguei; discussion sur les caractères fondamentaux d'un cycle de Coccidie. Z. Parasitenkd. 38: 250-270.

LEVINE N.D. 1982: Some corrections in haemogregarine (Apicomplexa: Protozoa) nomenclature. J. Protozool. 29: 601-603.

MAHNERT V. 1972: Grahamella und Sporozoa als Blutparasiten alpiner Kleinsäuger. Acta Trop. 29: 88-100.

NEMIROV K., VAPALAHTI O., LUNDKVIST A., VASILENKO V., PLYUSNINA A., NIEMIMAA J., LAAKKONEN J., HENTTONEN H., VAHERI A., PLYUSNIN A. 1999: Isolation and characterization of Dobrava hantavirus carried by striped field mice (Apodemus agrarius) in Estonia. J. Gen. Virol. 80: 371379.

PANCIERA R.J., MATHEW J.S., EWING S.A., CUMMINGS C.A., DROST W.T., KOCAN A.A. 2000: Skeletal lesions of canine hepatozoonosis caused by Hepatozoon americanum. Vet. Pathol. 37: 225-230.

SAVITSKII B.P., KULNAZAROV B.K. 1988: [Ectoparasites and phoresants of the root vole (Microtus oeconomus Pall.) in the Polesye]. Parazitologiia 22: 372-377. (In Russian.)

SMITH T.G. 1996: The genus Hepatozoon (Apicomplexa: Adeleina). J. Parasitol. 82: 565-585.
SOVERI T., HENTTONEN H., RUDBÄCK E., SCHILT R., TANSKANEN R., HUSU-KALLIO J., HAUKISALMI V., SUKURA A., LAAKKONEN J. 2000: Disease patterns in field vole and bank vole populations during a cyclic decline in central Finland. Comp. Immunol. Microbiol. Infect. Dis. 23: 73-89.

ŠEBEK Z. 1975: Parasitische Gewebeprotozoen der wildlebenden Kleinsäuger in der Tschechoslowakei. Folia Parasitol. 22: 111-124.

ŠEBEK Z. 1978: Blood parasites of small mammals in western Hungary. Parasitol. Hung. 11: 17-22.

ŠEBEK Z., SIXL W., STÜNZNER D., VALOVÁ M., HUBÁLEK Z., TROGER H. 1980: Zur Kenntnis der Blutparasiten wildlebender Kleinsäuger in der Steiermark und im Burgenland. Folia Parasitol. 27: 295-301.

TURNER C.M.R. 1986: Seasonal and age distributions of Babesia, Hepatozoon, Trypanosoma and Grahamella species in Clethrionomys glareolus and Apodemus sylvaticus populations. Parasitology 93: 279-289.

TURNER C.M.R., COX F.E.G. 1985: Interspecific interactions between blood parasites in a wild rodent community. Ann. Trop. Med. Parasitol. 79: 463-465.

WALTER G., LIEBISCH A. 1980: Untersuchungen zur Ökologie einiger Blutprotozoen bei wildlebenden Kleinsäugern in Norddeutschland. Acta Trop. 37: 31-40.

WIGER R. 1979: Seasonal and annual variations in the prevalence of blood parasites in cyclic species of small rodents in Norway with special reference to Clethrionomys glareolus. Holarct. Ecol. 2: 169-175.

YANAI T., ATSUSHI T., MASEGI T., ISHIKAWA K., IWASAKI T., YAMAZOE K., UEDA K. 1995: Histopathologic features of naturally occurring hepatozoonosis in wild martens (Martes melampus) in Japan. J. Wildl. Dis. 31: 233-237.

Accepted 12 March 2001 